\title{
Regionalization and Public Investment: Analysis of the transfers of the Ministry of Tourism (MTur) in the state of Rio de Janeiro
}

\author{
Rodrigo Cardoso da Silva, Maria Aparecida Pontes Fonseca
}

\author{
Keywords: \\ PRT, \\ Public investment in \\ Tourism \\ Public Tourism Policy, \\ Ministry of Tourism.
}

Article History:

Submitted: 07.05.2021

Accepted: 20.12.2021

\begin{abstract}
This article is dedicated to understanding the intertwining of two materializations of public Tourism actions, namely: the Tourism Regionalization Program (PRT) and the investments made by the Ministry of Tourism (MTur). This is a gap in the studies of public tourism policies, when trying to understand the effectiveness of public actions by the applied financial instruments (Gonzalez, 2014). Thus, it is intended to align the resources allocated to the municipalities with the Tourism Regionalization Map, in order to spatialize these actions, discover possible concentrations and deepen the debate about ministerial action. Then, it is also intended to classify the use of public resources into categories of use (1 - Public Square; 2 - Event Support; 3 - Infrastructure; 4 - Urbanization; 5 Management Actions; 6 - Attractions; 7 - Gantries; 8 - Tourist Sign). The spatial focus of the research will be the state of Rio de Janeiro, the choice of this federative unit was due to its significant power of attracting international tourists, as well as being a consolidated destination in the Brazilian domestic market. The time frame starts in 2004, as it is the first year of implementation of the Tourism Regionalization Program (PRT), and ends in 2016, due to the data from the Transfer Contracts System of the Ministry of Tourism (SIACOR) having this limitation. About 478 agreements established between MTur and the municipalities of RJ were analyzed. The main results point to a distribution of resources without technical criteria. Among the 10 municipalities that received the most resources from MTur, at least 4 (São João do Meriti, Itaborai, Maricá and Nova Iguaçu) have no tourist representation and no relevant tourist attractions, or even belong to Tourism production chains. The main category of use of MTur resources in RJ are: Infrastructure (30.3\%), Urbanization (21\%) and Public Squares $(19.5 \%)$. The development of tourist attractions accounted for only $9.1 \%$ of all investment. In addition, the research points to important tourist municipalities in the state of $R J$ (Itatiaia and Cabo frio) that did not receive any agreement or funding from MTur. This paper contributes to elucidating the way MTur operates through the distribution of resources and their uses for the development of Tourism policies in the last decade.
\end{abstract}

\section{Doi: https://doi.org/10.31822/jomat.2021-SP-1-133}

\section{Introduction}

The participation of the Brazilian State in public Tourism policies has been consolidated since the 1990 s, when the first state planning instruments for the Tourism sector were developed (Cruz, 2002). Between 1990 and 2003, government action was based on public policy programs, two of which stood out in this context, the Tourism Development Program (PRODETUR) and the National Tourism Municipalization Program (PNMT).

The first program, respectively, made significant investments in basic and tourist infrastructure, which was heavily concentrated in the northeast region, and was responsible for promoting Tourism on the coast (Cruz, 2002; Fonseca, 2005). The second program was dedicated to training public managers and entrepreneurs to manage the development of Tourism at the municipal level (Brusadin, 2005).

In 2004, the newly created Ministry of Tourism launched the PRT (Tourism Regionalization Program) that drastically changed the way to encourage the development of Tourism in the country, considering as a parameter the tourist region. Since then, a national effort has begun in the country to plan and organize the tourist regions, in 2004, at the beginning of the program,

Corresponding Author

Rodrigo Cardoso da Silva: Prof., Federal Institute of Brasilia Department of Tourism, Hospitality and Leisure, Brazil, Email: 
219 tourist regions were presented (Brasil, 2004). In 2019, the Tourism Regionalization Map identified 333 regions, a growth of 109 since the beginning of the process (Brasil, 2019).

In general, the tourist regions were created with specific purposes, among them, four gain prominence, they are: 1 - Plan and treat each tourist region with its characteristics and peculiarities; 2 - Internationalize Tourism products with the Brazilian essence; 3 - Promote the expansion of Tourism activity throughout the country; 4 - Create instances of governance to produce synergy between the government and the private sector, in addition to mobilizing civil society (Brasil, 2003, 2007, 2013b, 2018b; Silva, 2015).

The PRT is one of the programs with the longest implementation horizon, considered a long-term public policy, with 17 years in 2021 already elapsed since its creation. However, the results and effectiveness of this policy are not yet evident. Furthermore, has the region actually become the center of attention for state action? What prevented the success of this public policy? Did the tourist municipalities integrated in tourist regions receive more resources coming from MTur? How were these resources used? These are some of the questions that we intend to answer in this paper.

It is understood that there are several ways to consider public policies, in this work, the analysis will be based on the transfers of public resources to perform actions and activities related to the development of public policies. According to González $(2006 ; 2014)$, one of the main difficulties of the management of tourist destinations in the context of public policies is in their financing. Therefore, it is relevant to investigate the dynamics of distribution of public resources for municipalities of tourist regions.

Within this context, the general objective is to understand the interweaving between the PRT and the public investments made by the Ministry of Tourism in the state of Rio de Janeiro. Delimited as specific objectives: A) to identify public investments made to tourist municipalities that are part of tourist regions. B) to identify how the resources were used in the municipalities. It is believed that this research can contribute to a technical analysis on the use of public resources intended for the development of Tourism ${ }^{1}$.

\section{Public Investment in Tourism}

Currently, it is noticeable that Tourism has entered the government agendas in order to encourage social development, economic growth, diversification of activities, increase international tourism receipts, increase employment, among other objectives. Contemporary modern society recognizes the expression of the Tourism phenomenon by its transversal capacity that affects and drives the service market in general. In this sense, tourist activity is an object of public interest and, consequently, attracts attention of the entire political class, directing efforts to create and manage specific policies for this activity in all spheres of public power (executive, legislative and judicial).

At the international level, developing countries that choose to bet on Tourism, and that do not yet have an economic expression in the capitalist market system, choose to face this issue by making available the resources present in their territories. Thus, to a large extent, natural resources, environmental and historical heritage are among the main potential attractions that are used to create a tourist supply to meet the demand for Tourism. However, this process of insertion and construction of the tourist market is not easy, since it is necessary to invest in many areas to consolidate tourist demand and become a competitive tourist destination. In this context, Tourism policies become necessary and their extension must be long-term, to reconcile the interests of all actors involved in the Tourism development process (Beni, 2006; González, 2006).

The triggering of the Tourism process requires investments in various sectors (infrastructure, professional qualification, tax incentives, financing, etc.) and for this reason, planning Tourism requires a wide legislative and financial apparatus. The investments that the government promotes in Tourism overflow and affect other areas of society, as it is an area with transversality (Banerjee et al., 2016).

Public investment in the Tourism sector is an action that is hardly possible to measure, because of its extension and its direct benefits. In Brazil, some researchers point out that this transversal capacity of Tourism has been misinterpreted, mainly in public policies and in investments directed by MTur, whose main consequence is the pulverized actions in various spheres,

1 This article is part of the doctoral thesis entitled "Parliamentary interference in the budget of the Ministry of Tourism: discourse and reality of public Tourism policies in Brazil”. 
predominantly actions in the area of infrastructure (Silva \& Fonseca, 2017; Todesco \& Silva, 2017). These works, for the most part, are punctual actions and disconnected from regional policies or local Tourism policies.

Regarding these specific actions, Silva and Fonseca (2017) and Silva (2015) point out that much of these investments come through parliamentary amendments that are linked to partisan political objectives and, therefore, far from the political proposals outlined by the National Tourism Plans, or even not aligned with the main difficulties and problems of local or regional Tourism management. This fact has been perpetuated for a long period and has contributed to the understanding of academia and scholars that Tourism policies are devoid of technical content.

Another movement that has been valued in public policies is decentralization ${ }^{2}$, so that the formation of boards and governance bodies are elements of decentralization in the policies of MTur, since 2004 (Coutinho, 2015; Nóbrega, 2012; Silva, 2015). Also on decentralization, it is important to emphasize that it can become a limiting factor and unable to improve externalities between municipalities, promoting unnecessary competition, if there is no alignment with regional political aspects ((KisKatos \& Sjahrir, 2017) since decentralization actions do not have rules and well-defined criteria, they can cause competition among those who must share power. It is added that the Union (federal power) has a decisive role in fiscal and decisionmaking decentralization, and perhaps this sphere of government is the one with the greatest capacity to promote, in the hierarchical chain of public power, the foundations for the decentralization of power, based on the trust placed in public policies (Sztompka, 2016).

In the context of Tourism, decentralization is not yet a reality, considering that the governance bodies created with this perspective only hold the advisory role, so that they do not deliberate on regional issues, or even between municipalities and state governments (Nóbrega, 2012; Silva, 2015, 2016). In addition, fiscal decentralization was considered as a necessary action in Tourism policies, since it is not enough to create advisory regional councils, it is essential to promote financial and institutional autonomy (González, 2016; Silva \& Fonseca, 2017; González, 2006).
Currently, public investments in various spheres of State action (health, education and the entire sphere of social security) have been operated by a movement of fiscal decentralization, that is, transfers are made directly from the Union to municipalities or state governments, according to its competence to act, to facilitate budget execution, as well as reduce political interference from other spheres of government (Moutinho, 2016).

For this reason, investment policy must also adapt to fiscal and decision-making decentralization. For more than a decade, Tourism policies have been promoting the formation of governance bodies to provide effective management of Tourism regions in the country, through the $\mathrm{PRT}^{3}$. However, no MTur study or document proves this alignment of what is invested with the needs and priorities of the tourist regions of the country.

In the area of Tourism, it is common for public actors to allocate resources for works in the areas of transport, mobility, sanitation, urban reform and landscaping, that is, designate these resources as investments in Tourism (Mazón, 2014). In fact, these areas corroborate with the development of the activity, but in many cases, the main issues or with greater urgency are not resolved by these investments. This fact happens when public investments and public policy guidelines are not aligned, this scenario is also of paramount importance for the present paper, to the extent that it reflects on the current situation of Tourism in the country, taking into account that there was public investment in municipalities and tourist regions in the country (Lemos, 2013; Silva \& Fonseca, 2017; Silva Junior \& Silva, 2019)

It is understood that investments in the Tourism area must, first of all, address the central issues of the practice of the activity, such as: infrastructure for existing attractions, management actions, regularization of the market, and improvement of local potential. Logically, the main demands being met, it is possible to indirectly benefit from various aspects of urbanization, aesthetics, as well as the quality of life in cities and tourist spaces (Yázigi, 2003a). In addition, it cannot be denied that what favors the quality of life of the resident, generates equal benefit for the practice of Tourism (Yázigi, 2003b).

According to Banerjee, Cicowiez, \& Cotta (2016), in countries that are still new to the tourist market,

\footnotetext{
2 Decentralization is related to increasing the decision-making power of smaller bodies on local issues, this aspect is interconnected with the implementation of governance as a model of public policies.
}

3 Tourism Regionalization Program started in 2004. 
one of the objectives of public investments is to improve aspects of the governance of destinations and the sector, in addition to creating favorable environments for the development of private initiatives. This recommendation of the authors is for countries that have few sources of financing and are not yet consolidated destinations, as they need to create market conditions to attract local and mainly foreign investment. In addition, they need an organization that addresses local conflicts and obstacles. In Brazil, the investment policy came before the establishment of Tourism governance actions, as an example, we can cite the policies of megaprojects and PRODETUR in the 1990s and 2000s (Duda \& Araujo, 2014; Fonseca, 2005; Paiva, 2010).

In short, government-level Tourism planning and management is still a primary challenge. In this sense, understanding the use of resources operated in the Tourism area helps us to map out how the Brazilian State has acted in the structuring and development of its destinations.

In this study, it was decided not to choose a specific theory on public policies and public budget (despite recognizing the application of several, such as: multiple flows, incrementalism, public policy cycle, among others). That is because, in a certain way, this choice could direct the researcher to specific aspects and categories already contemplated in existing theories. In this sense, we sought to investigate public investments and to find new ways to reflect specifically on the reality of Brazil, with emphasis on the budget and public Tourism policies. This challenge was faced by understanding that it is thus possible to conduct a process of induction of new knowledge, and reflections arising from the reality of the budget for Tourism.

\section{Study Methodology}

Rio de Janeiro (RJ) is adopted as a spatial focus for this research, as it is the state with the highest tourist representation in Brazil, being this the main tourist destination of the country. According to the study of international tourist demand, $70 \%$ of tourists go to RJ with leisure intentions, and the main segment is sun-and-beach Tourism (60\%), followed by the segment of nature, ecotourism and adventure (19\%) and, finally, culture (18.2\%) (Brasil, 2018a). According to the study of domestic travel demand, RJ's estimate of domestic demand in 2012 was about five million tourists annually (Brasil, 2012). In this sense, the state becomes ideal to analyze the function and distribution of MTur resources for municipalities belonging to tourist regions.

The time frame of the research was established between 2004 and 2016, this choice was made by the use of the Transfer Contracts System ${ }^{4}$ (SIACOR) database, where it was possible to collect all the transfer agreements concluded between MTur and the municipalities of RJ. This specific database only contains information until 2016, because there were significant changes in the databases with the Government of Michel Temer,

Table 1: Tourist regions and number of tourist municipalities in RJ

\begin{tabular}{|c|c|c|c|c|c|c|c|c|}
\hline \multirow{13}{*}{ 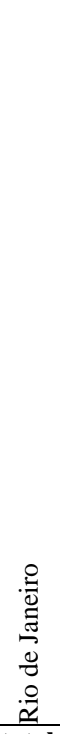 } & $\begin{array}{c}\text { Tourist } \\
\text { regions } \\
(2006) \\
\end{array}$ & $\begin{array}{c}\text { Number of } \\
\text { municipalities }\end{array}$ & $\begin{array}{l}\text { Tourist regions } \\
(2009)\end{array}$ & $\begin{array}{c}\text { Number of } \\
\text { municipalities }\end{array}$ & $\begin{array}{c}\text { Tourist regions } \\
(\mathbf{2 0 1 3 )}\end{array}$ & $\begin{array}{c}\text { Number of } \\
\text { municipalities }\end{array}$ & $\begin{array}{c}\text { Tourist regions } \\
\text { (2016) }\end{array}$ & $\begin{array}{c}\text { Number of } \\
\text { municipalities }\end{array}$ \\
\hline & $\begin{array}{l}\text { Agulhas } \\
\text { Negras }\end{array}$ & 4 & Agulhas Negras & 4 & Agulhas Negras & 4 & Agulhas Negras & 4 \\
\hline & Metropolitana & 2 & Metropolitana & 2 & Metropolitana & 2 & Metropolitana & 2 \\
\hline & Costa do Sol & 13 & Costa do Sol & 13 & Costa do Sol & 13 & Costa do Sol & 13 \\
\hline & $\begin{array}{l}\text { Serra Verde } \\
\text { Imperial } \\
\end{array}$ & 10 & $\begin{array}{l}\text { Serra Verde } \\
\text { Imperial }\end{array}$ & 5 & $\begin{array}{l}\text { Serra Verde } \\
\text { Imperial } \\
\end{array}$ & 5 & $\begin{array}{l}\text { Serra Verde } \\
\text { Imperial } \\
\end{array}$ & 5 \\
\hline & Costa Verde & 5 & Costa Verde & 5 & Costa Verde & 5 & Costa Verde & 5 \\
\hline & Vale do Café & 14 & Vale do Café & 13 & Vale do Café & 13 & Vale do Café & 12 \\
\hline & \begin{tabular}{|l} 
Baixada \\
Fluminense \\
\end{tabular} & 9 & \begin{tabular}{|l} 
Baixada \\
Fluminense \\
\end{tabular} & 10 & \begin{tabular}{|l} 
Baixada \\
Fluminense \\
\end{tabular} & 10 & $\begin{array}{l}\text { Baixada } \\
\text { Fluminense } \\
\end{array}$ & 5 \\
\hline & Serra Norte & 12 & Serra Norte & 11 & Serra Norte & 11 & \begin{tabular}{|l} 
Caminho da \\
Serra
\end{tabular} & 7 \\
\hline & $\begin{array}{l}\text { Caminhos da } \\
\text { Mata }\end{array}$ & 5 & $\begin{array}{l}\text { Caminhos da } \\
\text { Mata }\end{array}$ & 5 & $\begin{array}{l}\text { Caminhos da } \\
\text { Mata } \\
\end{array}$ & 5 & $\begin{array}{l}\text { Caminhos da } \\
\text { Mata }\end{array}$ & 5 \\
\hline & Costa Doce & 5 & Costa Doce & 5 & Costa Doce & 5 & Costa Doce & 2 \\
\hline & $\begin{array}{l}\text { Noroeste das } \\
\text { Águas }\end{array}$ & 13 & $\begin{array}{l}\text { Noroeste das } \\
\text { Águas }\end{array}$ & 13 & $\begin{array}{l}\text { Águas do } \\
\text { Noroeste }\end{array}$ & 13 & $\begin{array}{l}\text { Águas do } \\
\text { Noroeste }\end{array}$ & 7 \\
\hline & - & - & $\begin{array}{l}\text { Caminhos } \\
\text { Coloniais }\end{array}$ & 6 & $\begin{array}{l}\text { Caminhos } \\
\text { Coloniais }\end{array}$ & 6 & $\begin{array}{l}\text { Caminhos } \\
\text { Coloniais }\end{array}$ & 4 \\
\hline total & 11 & 92 & 12 & 92 & 12 & 92 & 12 & 71 \\
\hline
\end{tabular}

Source: Mapas do turismo brasileiro (Brazilian Tourism Maps) (Brasil, 2004, 2009; 2013a; 2016) 
and thus the information began to be hosted in other systems with different formats, such as the Transparency Portal, Plataforma Mais Brasil, among others. The main result we tried to achieve was to identify where, how much and what amounts were allocated to tourist municipalities, considering producing a detailed analysis.

To systematize and present the data, we chose to produce cartographic maps in order to demonstrate the concentrations of public resources in certain municipalities. The spatial analyses were divided into four periods, namely: 2004/2006, 2007/2010, $2011 / 2014$ and 2015/2016. This division was carried out in order to facilitate the comparison of the volume of resources destined to municipalities, and whether they were contemplated in tourist regions. Following is Table 1 with information about the tourist regions in RJ, as well as the number of municipalities in each region.

RJ has 92 municipalities and all were considered tourist in the regionalization of 2006, 2009 and 2013. The number of tourist municipalities in RJ only declined to 71 in the regionalization of 2016 . In relation to the number of tourist regions, another tourist region was added - Caminhos Coloniais in the regionalization of 2009, totaling 12 tourist regions that remain to this day.

The process of regionalization of Tourism in Brazil has undergone several changes over time, these changes covered several areas, some are mentioned: 1 - name change of the tourist regions; 2 - creation and exclusion of regions; 3 -inclusion and exclusion of municipalities (Fonseca et al., 2019; Silva, 2016). Therefore, to reduce these distortions and problems, a map of the reference regionalization was adopted for each temporal division of the analyses. Thus, for the first period, the regionalization of 2006 was used, for the second the regionalization of 2009 , for the third the regionalization of 2013 and finally, for the fourth period the regionalization of 2016. Despite the regionalization of RJ being a one of the most stable in terms of the number of municipalities and tourist regions, it maintained the periodization in four periods, in order to offer more details about the investments.

On the maps, the municipalities that received resources from MTur according to each time frame are highlighted in green. An intensifying color scale (going from lighter to darker green) was used to represent the investment concentrations. Six investment and color scales were defined, ranging from 0 (zero) to above 4 (four) million Brazilian Reais.

It is important to note that all agreements signed by MTur were accounted for, regardless of the situation $^{5}$, because it was considered that there was the availability of public resources at the federal level to the municipalities, in addition, there is a range of factors that can lead to the cancellation of the transfer from the inability to elaborate projects, to the political will to change the object of investment.

To identify the use of the resource and classify it into categories for objective evaluation, the categories presented and detailed in Chart 1 below were adopted.

Chart 1: Category of uses of public resources.

\begin{tabular}{|l|l|}
\hline CATEGORIES & DESCRIPTION OF OBJECTS \\
\hline 1 - Construction of Public Squares & Implementation, reform, revitalization of public squares and other interventions in squares. \\
\hline $2-$ Event Support & $\begin{array}{l}\text { Event sites, exhibition parks, convention centers and similar physical structures that aim to promote } \\
\text { events. }\end{array}$ \\
\hline $3-$ Infrastructure & $\begin{array}{l}\text { Handicraft centers, sports gyms, tourist and bus terminals, kiosks, renovation or revitalization of } \\
\text { buildings, implementation of infrastructure, marinas, acquisition of equipment. }\end{array}$ \\
\hline $4-$ Urbanization & $\begin{array}{l}\text { Paving, asphalting of roads, improvement of accesses, revitalization of public spaces, drainage works } \\
\text { and deployment of bridges to improve access. }\end{array}$ \\
\hline $5-$ Activity Management Actions & Plans and projects whose purpose is the planning for tourist activities in municipalities and states. \\
\hline $6-$ Tourist Attractions & $\begin{array}{l}\text { Support to tourist attractions, renovation, requalification of shores, trails, viewpoints and parks, } \\
\text { implantation of a tourist complex. Works with the purpose of providing improvement of beaches and } \\
\text { resorts. }\end{array}$ \\
\hline $7-$ Gantries & $\begin{array}{l}\text { Infrastructure for signaling the entrances and exits of urban areas, renovation or revitalization of } \\
\text { gantries. }\end{array}$ \\
\hline $8-$ Tourist Sign & Signaling of tourist places or spaces in municipalities. Signaling or plate revitalisation system. \\
\hline
\end{tabular}

Source: Adapted from Silva (2015), Lima (2017) and Silva Junior e Silva (2019). 
These categories of public resource use presented in the chart above were based on some previous research, such as Silva (2015), Lima, (2017) e Silva Junior, Silva (2019). It is noteworthy that the categories of use of resources represent a methodological effort to synthesize numerous agreements/contracts that were concluded in this study, the main objective being to understand the use of public resources.

As the final stage of the analysis, the panorama of the 10 municipalities that received the most resources will be evaluated. The study follows a quantitative approach, using descriptive analyses. The data tabulation was done with the help of the Excel software, using descriptive statistics on the contributions of resources and accounting.

Finally, we emphasize the investigative character of this work in an attempt to formulate theoretical elements on the process of planning and execution of public Tourism policies in Brazil, and that for this reason no specific theory or theoretical categories were determined, to have greater freedom of analysis and observation of reality.

\section{Analysis of Public Investments in Rio De Janeiro}

The analysis of the results begins by showing the volume of resources transferred by MTur to the municipalities of RJ by period of time, investment volume and municipal counterparts. This information is presented in Table 02 below.
Table 2: Summary of investments of MTur transfers in RJ (BRL) - 2004/2016.

\begin{tabular}{|l|l|l|}
\hline Periods & Investment Volume & Municipal counterparts \\
\hline $2004-2006$ & 40.803 .000 .00 & 8.625 .513 .10 \\
\hline $2007-2010$ & 121.871 .244 .50 & 25.153 .454 .80 \\
\hline $2011-2014$ & 112.854 .122 .50 & 12.479 .202 .40 \\
\hline $2015-2016$ & 29.720 .556 .00 & 5.260 .863 .70 \\
\hline Total & 305.248 .923 .00 & 51.519 .034 .00 \\
\hline
\end{tabular}

Source: SIACOR, MTur. Authors' elaboration.

To better understand the dynamics of the distribution of public resources and their application in the municipalities of Rio de Janeiro, the results were separated by periods according to Table 02. Thus, it is intended to deepen and reference the resource concentrations in each time frame.

\section{Distribution of Resources Between 2004 and 2006}

Between 2004/2006, approximately BRL 40 million were distributed to 49 municipalities (53.2\%) that concluded agreements/contracts with MTur, reaching a volume of 104 agreements. In this scenario, 43 municipalities had no investments, even though they were considered touristic and members of tourist regions. This analysis can be visualized in Map 1, which shows that there is a considerable proportion of municipalities with the lowest investment scale. In contrast, the largest sums of resources were concentrated in five municipalities (Niterói, Rio das Flores, Maricá, Petrópolis and Angra dos Reis). The municipality of Niterói has prominence in this time frame, because it concentrated, alone, about BRL 7 million in resources.

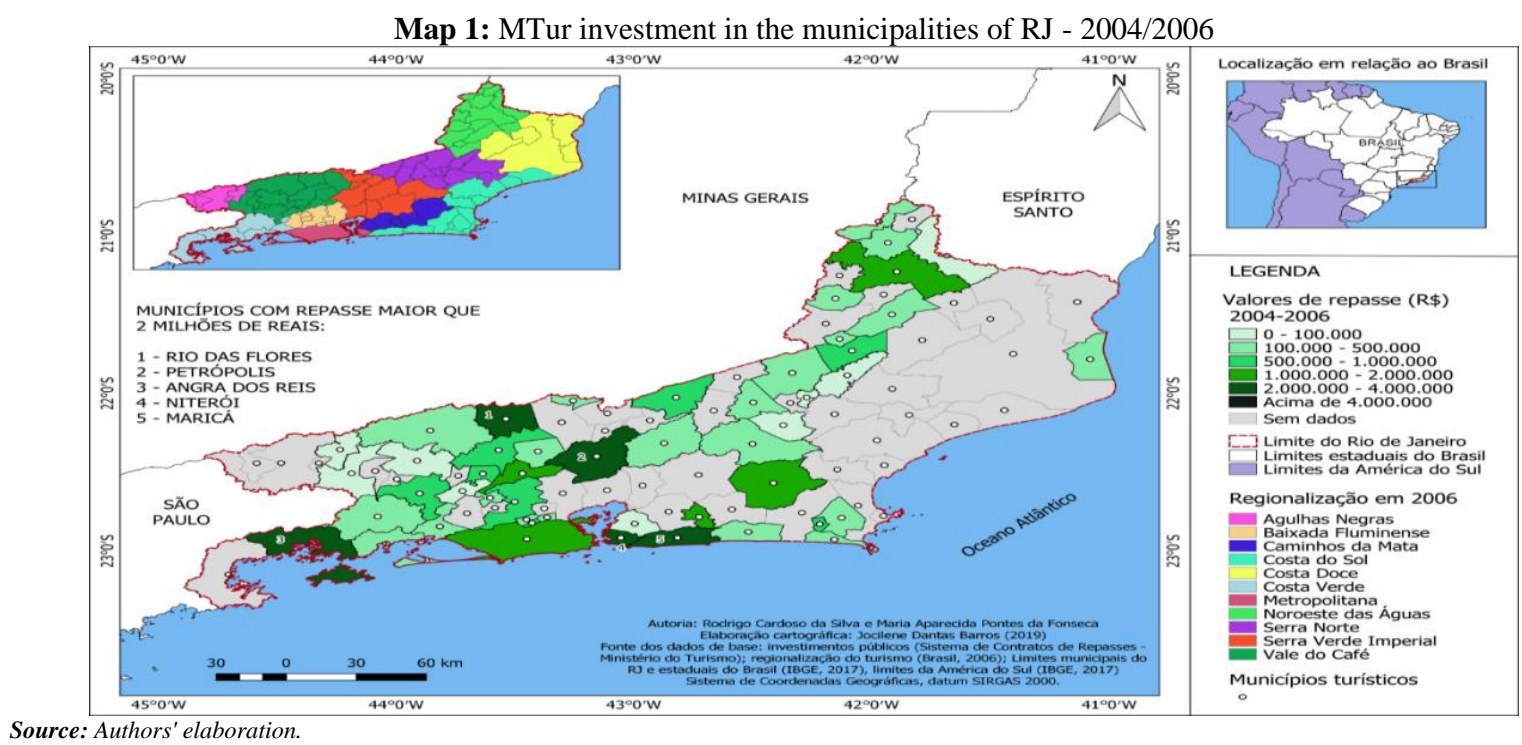

Source: Authors' elaboration. 
Next, Map 1 with the spatialization of public investments in the state of RJ.

In this spatial focus of 2004-2006, it is noticed that the tourist regions of Costa do Sol, Serra Verde Imperial and Costa Doce had few municipalities served by public resources.

It is noticeable in the previous map that the investment category of BRL 1 million to BRL 2 million contemplated six municipalities (Itaperuna, Rio de Janeiro, Silva Jardim, Tanguá, Miguel Pereira, Nova Iguaçu), which represent $12.2 \%$ of investments. Itaperuna had the largest investment (BRL 1.3 million) of this group, however, this municipality was not considered as a municipality with tourist representation, and even today, it is configured as an industrial municipality in the north of the state.

In the category of BRL 500 thousand up to BRL 1 million, a group of nine municipalities was formed (Itaocara, Pirai, Engenheiro Paulo de Frontin, Vassouras, Nilópolis, Iguaba Grande, Sapucaia, Cambuci and Valença), most of them located in the interior of the state of RJ. With the exception of Vassouras, the other municipalities do not have potential attractions that justify the investments they received.

In the BRL 100 thousand to BRL 500 thousand category, most of the investment was concentrated in 29 municipalities representing the largest portion, around $59 \%$, of the total municipalities with investment in RJ. Thus, in this time frame, there was an intense spraying of public resources.
In this sense, it should be noted that Paraty and Cabo Frio are municipalities that have not received investment, but were already consolidated tourist destinations.

Between 2004 and 2006, a volume of about BRL 40 million was invested throughout the state of RJ, noting that the tourist region of Costa Doce obtained the least amount of resources, having only one municipality of this region contemplated. In this scope, the distribution of resources found in Map 1 does not appear to follow technical criteria or a planned order of Tourism Development.

\section{Distribution of Resources Between 2007 and 2010.}

Continuing with the analysis of investments, the study turns to the second time frame of 2007-2010, which is one of the broader investment segments. The regionalization that was used as a parameter is that of 2009. In this regionalization, RJ added another tourist region (Caminhos Coloniais6), which resulted in a total of 12 tourist regions, but the number of tourist municipalities remained 92 . Next, Map 2 is presented with the spatialization of public investments of MTur, in the period 2007 2010.

According to Map 2, 67 (73\%) municipalities with MTur investments were considered in the state of RJ. In this period, a total of 226 agreements/contracts were signed with the municipalities, and it should be noted that 25 municipalities considered touristic were no longer served in this period of analysis.

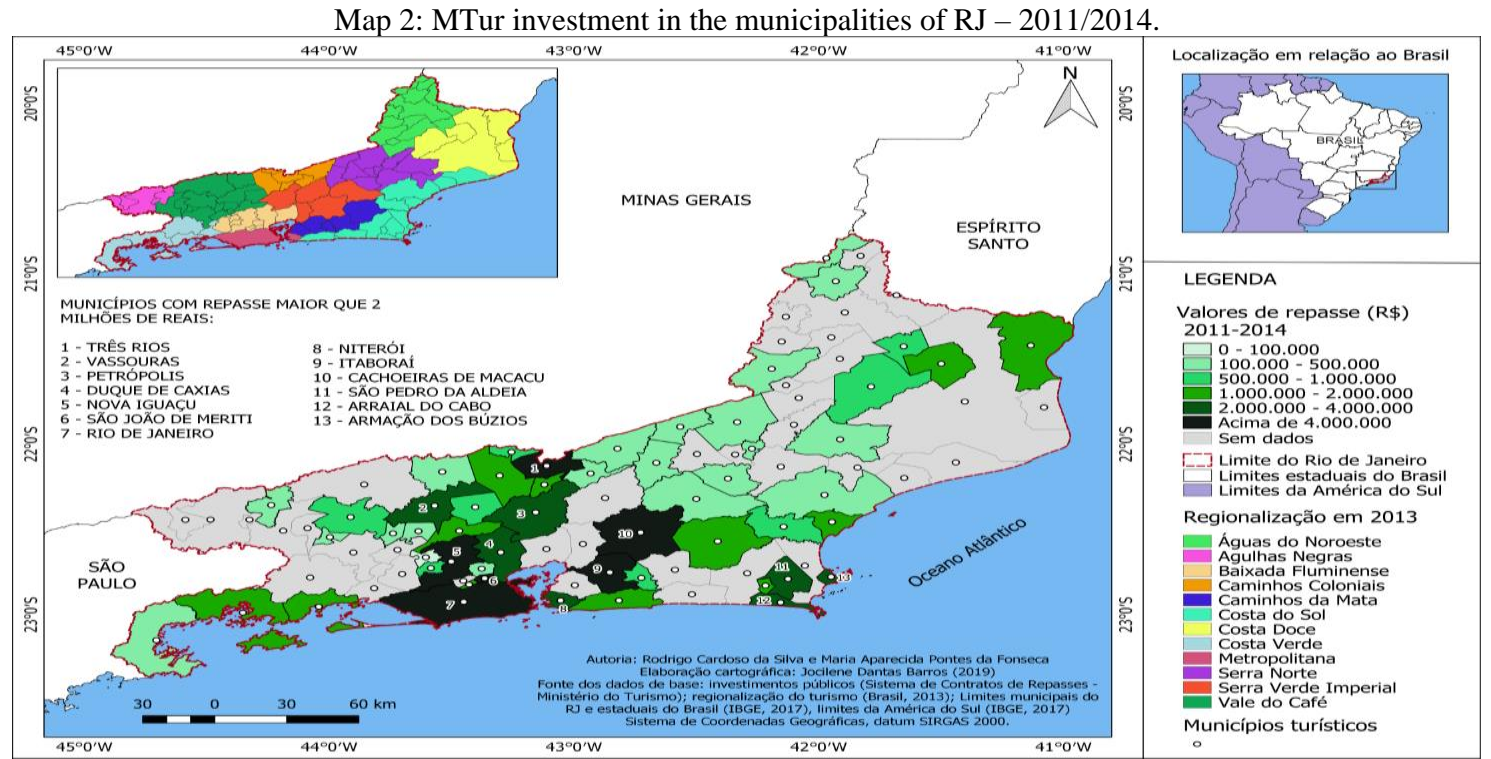

Source: Authors' elaboration.

6 The Caminhos Coloniais region was created by the separation of municipalities with borders with Minas Gerais, the municipalities that formed the new region were: 1 -Areal, 2 - Comendador Levy Gasparian, 3 - Paraíba do Sul, 4 - São José do Vale do Rio Preto, 5 - Sapucaia and 6 - Três Rios. 
The largest investments, above BRL 4 million, were concentrated in six municipalities (about 6.5\%), namely: São João do Meriti (BRL 24.9 million), Paraty (BRL 7.9 million), Rio de Janeiro (BRL 7.2 million), Armação de Búzios (BRL 5.4 million), Nilópolis (BRL 4.7 million) and Angra dos Reis (BRL 4.1 million). These municipalities, alone, concentrated about BRL 53 million out of a total of BRL 121 million, representing a little more than $43 \%$ of the four-year investments.

In the BRL 2 to BRL 4 million category, this group covered 8 municipalities (8.7\%), namely: 1 Valença (BRL 3.7 million), 2 - Maricá (BRL 3.6 million), 3 - Duque de Caxias (BRL 2.8 million), 4 - Niterói (BRL 2.6 million), 5 - Resende (BRL 2.3 million), 6 - Rio Claro (BRL 2.2 million), 7 Teresópolis (BRL 2.2 million) and 8 - Petrópolis (BRL 2.1 million). In this group, only three municipalities have a certain tourist representation, being them: Niterói, Teresópolis and Petrópolis.

In the category of values averaged from BRL 1 to BRL 2 million, 20 municipalities (about $21.7 \%$ ) were on this investment scale. There are still 16 municipalities (about 17.4\%) with investments of BRL 500 thousand to BRL 1 million and, finally, 14 municipalities (about 15.2\%) in the investment category of BRL 100 thousand to BRL 500 thousand.

In the period 2007-2010, approximately BRL 121.8 million were distributed to the municipalities of RJ, a volume three times greater compared to the previous period (2004 - 2006). Most of the resources were concentrated on the coast of RJ, as well as for the municipalities near the capital. This same scenario was observed in the state of Rio Grande do Norte (RN).
The case of the municipality of São João do Meriti, located near the municipality of Rio de Janeiro, which had the highest concentration of resources, was surprising. However, the market and tourist attractions of this municipality are not expressive, nor do they offer complementarity to another destination of the state, a situation that will be investigated later.

In this time frame (2007-2010), resources were more concentrated than in the previous one, although the volume of resources was significantly higher. There is a relevant number of municipalities in the smallest investment bands. It is also noticeable that there is a greater number of municipalities with values above BRL 4 million. It is noteworthy that even with a small amount of municipalities in RJ, about 25 ceased to be benefited from the Ministry's resources. According to the volume of resources of 2007-2010, as well as considering the territorial extent of RJ, it would be possible to serve the 92 tourist municipalities of the state.

It is noticed that there is a force that operates and directs these resources to specific municipalities; it is considered that this direction is made by parliamentarians, through individual and bench amendments. According to Silva (2015) and Todesco and Silva, (2021), it is possible to observe this trend of parliamentary action when studying the budget and its composition in the Tourism portfolio.

\section{Distribution of Resources Between 2011 and 2014.}

The following is the next time frame of investment, which includes the years from 2011 to 2014 , as well as the Tourism Regionalization Map of 2013, which was used as a parameter to identify the tourist municipalities. Next, Map 3 with the spatialization of resources in the state of $\mathrm{RJ}$.

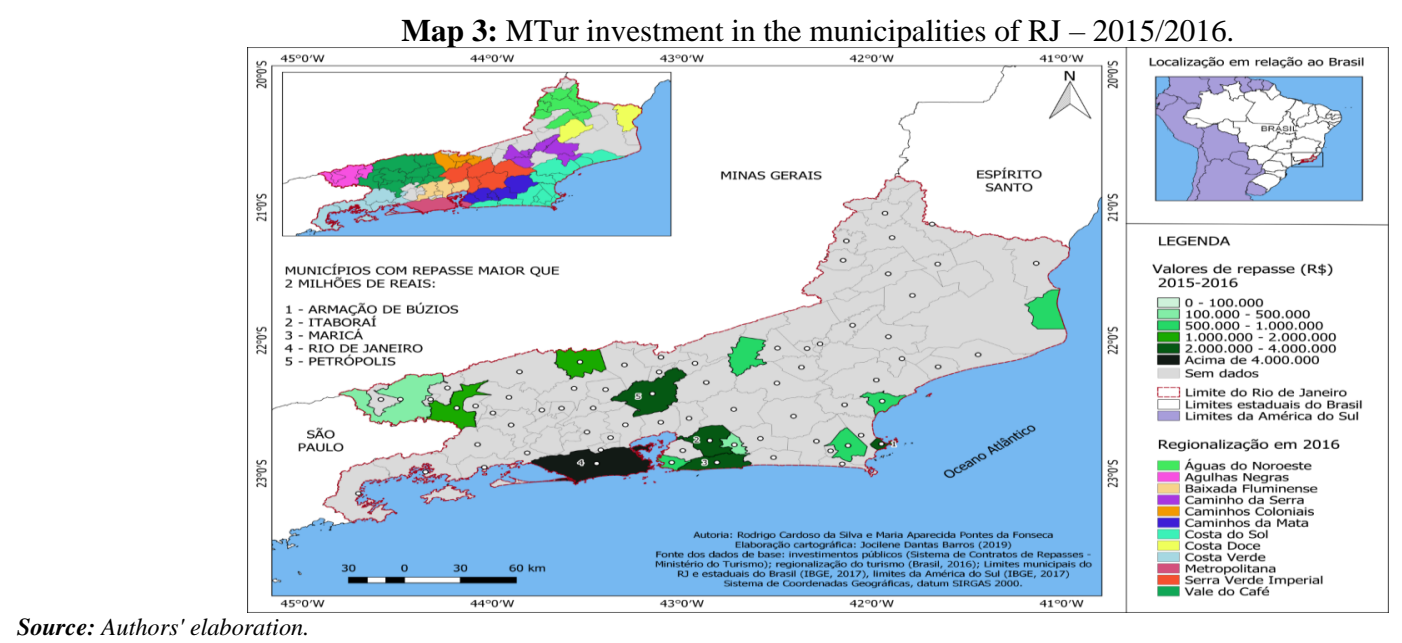


It should be noted that there was no change in the number of tourist municipalities in the state of RJ, remaining 92 according to the Tourism Regionalization Map in 2013. The time frame of Map 3 shows a spatialization of 54 (58.6\%) municipalities with MTur resources, which concluded 119 agreements/contracts with the contribution of BRL 112 million.

In the range of investments above BRL 4 million, only six municipalities stand out: 1 - Rio de Janeiro (BRL 28.2 million), 2 - Itaboraí (BRL 10.3 million), 3 - Nova Iguaçu (BRL 7.3 million), 4 - São João do Meriti (BRL 5.9 million), 5 - Cachoeira do Macacu (BRL 4.7 million) and 6 - Três Rios (BRL 4.4 million). It should be added that this range of investment concentrated around 61 million, that is, more than half of the resources distributed in this time frame.

In the category of BRL 2 to BRL 4 million invested, there are seven municipalities, they are: 1 Armação de Búzios (BRL 3.8 million), 2 - Niterói (BRL 3.8 million), 3 - São Pedro da Aldeia (BRL 3.1 million), 4 - Duque de Caxias (BRL 2.9 million), 5 - Arraial do Cabo (BRL 2.9 million), 6 - Petrópolis (BRL 2.4 million) and 7 - Vassouras (BRL 2.0 million). This category agglomerated about BRL 21 million. It is noteworthy that the municipalities of Itaboraí, Nova Iguaçu and São João do Meriti have a considerable contribution of resources, but these municipalities do not have an expression in the market and tourist attractiveness of RJ.

In the category of BRL 1 to BRL 2 million investment, a group of 12 municipalities was formed, which concentrated about BRL 17 million. The other 30 municipalities were in the two lowest investment range. The Agulhas Negras tourist region was the region with the lowest investment, followed by Águas do Noroeste. This data coincides with the data on the decrease in the Ministry's budget (Todesco e Silva, 2021).

Distribution of Resources Between 2015 and 2016.

Next, Map 4 displays the last time frame of investment, and the regionalization of the year 2016 was used to identify the tourist municipalities. It is noteworthy that there was a change in the number of tourist municipalities from 92 to 71 tourist municipalities. The state of RJ decreased 21 tourist municipalities, however, the number of tourist regions remained the same (12 regions).

The tourist regions that lost municipalities were Águas do Noroeste and Costa Doce. Another change that happened was the name change of the Serra Norte region in 2013, which was renamed Caminhos da Serra in 2016.

In this last time frame represented on Map 4, only 14 municipalities were identified and 29 agreements/contracts were established. The contribution of resources was around BRL 29 million, the lowest amount invested. The municipality of Rio de Janeiro is the only municipality with investments above BRL 4 million, to be more precise, about BRL 8 million were invested.

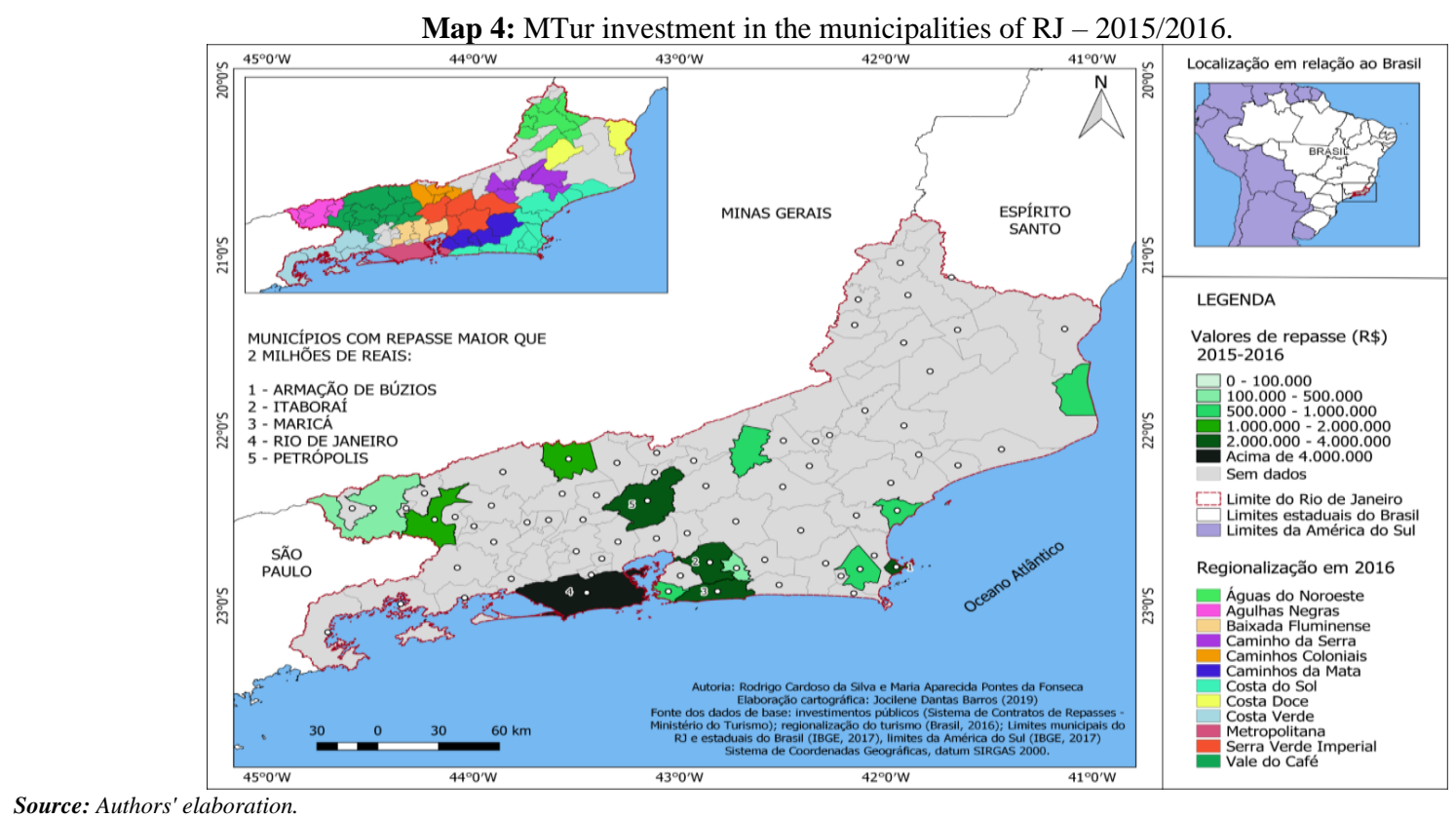

Source: Authors' elaboration 


\section{Jomat}

In this time frame, four municipalities obtained investments ranging from BRL 2 to BRL 4 million, they are: 1 - Itaboraí (BRL 3.8 million), 2 Armação De Búzios (BRL 2.3 million), 3 - Maricá (BRL 2.3 million) and 4 - Petrópolis (BRL 2.2 million).

In the category of BRL 1 to BRL 2 million, only three municipalities obtained such values, these being: 1 - Tanguá (BRL 1.7 million), 2 - Rio das Flores (BRL 1.2 million) and 3-Barra Mansa (BRL 1.0 million). The other six municipalities are located in the lowest investment categories, below BRL 1 million. With the reduction of tourist regions in this time frame, two municipalities that are not part of the regionalization of Tourism received resources, they are: São João da Barra and Sumidouro. These municipalities received, respectively, BRL 580 thousand and BRL 975 thousand in investments.

In the period 2004-2013, the state of Rio de Janeiro presented the peculiarity of having all its municipalities considered touristic and integrated into the tourist regionalization. Next, Table 3 presents a summary of information on the number of municipalities served in the state, as well as those considered touristic or not.

Table 2 presents an interesting scenario, in which it is highlighted that all investments were made in municipalities considered touristic, since the whole state was considered touristic from 2006 to 2013. The periods with the highest number of tourist municipalities contemplated with investments are $2007 / 2010$ and 2011/2014. On the other hand, it is noteworthy that there is a significant amount of
Chart 2: List of Touristic Municipalities without MTur investment (2004/2016).

\begin{tabular}{|l|l|l|l|}
\hline $\begin{array}{c}\text { Tourist } \\
\text { municipality } \\
\text { in 2006 }\end{array}$ & $\begin{array}{c}\text { Tourist } \\
\text { municipality } \\
\text { in 2009 }\end{array}$ & $\begin{array}{c}\text { Tourist } \\
\text { municipality } \\
\text { in 2013 }\end{array}$ & $\begin{array}{c}\text { Tourist } \\
\text { municipality } \\
\text { in 2016 }\end{array}$ \\
\hline Araruama & Araruama & Araruama & Araruama \\
\hline Cabo Frio & Cabo Frio & Cabo Frio & Cabo Frio \\
\hline Carapebus & Carapebus & Carapebus & Carapebus \\
\hline $\begin{array}{l}\text { Conceição de } \\
\text { Macabu }\end{array}$ & $\begin{array}{l}\text { Conceição de } \\
\text { Macabu }\end{array}$ & $\begin{array}{l}\text { Conceição de } \\
\text { Macabu }\end{array}$ & $\begin{array}{l}\text { Conceição de } \\
\text { Macabu }\end{array}$ \\
\hline Guapimirim & Guapimirim & Guapimirim & Guapimirim \\
\hline Itatiaia & Itatiaia & Itatiaia & Itatiaia \\
\hline Magé & Magé & Magé & Magé \\
\hline $\begin{array}{l}\text { São José de } \\
\text { Ubá }\end{array}$ & $\begin{array}{l}\text { São José de } \\
\text { Ubá }\end{array}$ & $\begin{array}{l}\text { São José de } \\
\text { Ubá }\end{array}$ & $*$ \\
\hline Seropédica & Seropédica & Seropédica & $*$ \\
\hline $\begin{array}{l}\text { Trajano de } \\
\text { Moraes }\end{array}$ & $\begin{array}{l}\text { Trajano de } \\
\text { Moraes }\end{array}$ & $\begin{array}{l}\text { Trajano de } \\
\text { Moraes }\end{array}$ & $*$ \\
\hline Varre-sai & Varre-sai & Varre-sai & $*$ \\
\hline
\end{tabular}

Source: SIACOR, Tourism Regionalization Map (2006, 2009, 2013, 2016) Authors' elaboration.

* municipalities that were no longer considered tourist in 2016.

tourist municipalities that were left without investment in all periods, even though the state has a reasonably smaller number of municipalities. In this sense, it was investigated which municipalities did not receive MTur's investments. Below, Chart 2 brings this survey.

When analyzing Chart 2 above, there are some interesting aspects. The first is the case of seven of these municipalities (Araruama, Cabo Frio, Carapebus, Conceição de Macabu, Guapimirim, Itatiaia, Magé) that despite participating in the PRT since 2006, did not receive any funds from MTur. The second case is the municipalities of São José de Ubá, Seropédica, Trajano de Moraes, Varre-sai, which were on the Regionalization Map

Chart 3: List of Touristic Municipalities without MTur investment (2004/2016).

\begin{tabular}{|c|c|c|c|}
\hline Tourist municipality in 2006 & Tourist municipality in 2009 & Tourist municipality in 2013 & Tourist municipality in 2016 \\
\hline Araruama & Araruama & Araruama & Araruama \\
\hline Cabo Frio & Cabo Frio & Cabo Frio & Cabo Frio \\
\hline Carapebus & Carapebus & Carapebus & Carapebus \\
\hline Conceição de Macabu & Conceição de Macabu & Conceição de Macabu & Conceição de Macabu \\
\hline Guapimirim & Guapimirim & Guapimirim & Guapimirim \\
\hline Itatiaia & Itatiaia & Itatiaia & Itatiaia \\
\hline Magé & Magé & Magé & Magé \\
\hline São José de Ubá & São José de Ubá & São José de Ubá & $*$ \\
\hline Seropédica & Seropédica & Seropédica & $*$ \\
\hline Trajano de Moraes & Trajano de Moraes & Trajano de Moraes & $*$ \\
\hline Varre-sai & Varre-sai & Varre-sai & $*$ \\
\hline
\end{tabular}

* municipalities that were no longer considered tourist in 2016. 
until 2013 and, soon after, ceased to be considered touristic.

These two observation points of Chart 2 present a reality that can help to understand a little about the fluctuations in the number of municipalities participating in the PRT, in which a group of municipalities remained active in the political guidelines and did not receive investments; this fact weakens the Tourism policy in its collaborative, synergistic and democratic values. In the other situation, municipalities that remained for a long period in the PRT and abandoned it, as they did not see any benefits or advances for being considered touristic.

These two situations undermine the confidence of public and private actors about the efficiency of the Tourism Policy. About this aspect, Sztompka (2016) emphasizes that it is a priority to maintain trust and establish a system that supports rules and criteria for all participants in the groups. The lack of technical criteria for applying and receiving appeal may be a factor that contributed to the inefficiency of the results of public actions.

Also in Chart 2, there are two prominent municipalities, they are: Cabo Frio and Itatiaia, highlighted in blue. Both municipalities are regional tourist destinations, having a representative market and tourist attractions. In the case of Itatiaia, the municipality holds, in its territory, the Itatiaia National Park (first national park created in 1937), which attracts a flow of people interested in the segments of nature Tourism, adventure and ecotourism (Hubner, 2013).

In addition, the District of Penedo, located in Itatiaia, near the National Park, attracts a significant flow of people from the region, because it houses the only Finnish colony in Brazil, as well as a consolidated market structure with accommodation, catering and entertainment equipment characteristic of tourist activity (Fagerlande, 2015, 2010). It is added that Itatiaia is a municipality belonging to the Agulhas Negras tourist region ${ }^{7}$.

The municipality of Cabo Frio belongs to the tourist region of Costa do Sol since 2006, and its main attraction is in the landscapes and beaches. According to Fonseca, (2011) Cabo Frio, Armação de Búzios and Arraial do Cabo are the three most important municipalities in the region when it comes to tourist activity. In addition, it should be noted that Cabo Frio has an airport and manpower training institutions, both primary services for the maintenance of Tourism (Fonseca, 2011). Next, Table 4 is presented with data on the market and economy of Tourism in Itatiaia and Cabo Frio.

In this scenario, the two municipalities presented reinforce the detachment of these investments with reality, making it more evident that there is a force that operates behind these investments, without using technical criteria. The detailed analysis of the investments reveals the political strength of the municipalities as a decisive element; this fact would explain the situation of São João do Meriti, Nova Iguaçu, among other municipalities, with significant contribution of resources, but without a strong representation of Tourism in these municipalities.

In general, about BRL 305 million were directed in the state of RJ, these resources were distributed in 81 municipalities, this represents $88 \%$ of the municipalities of the state. Observing the concentrations of investments demonstrated so far, it is not possible to affirm that technical elements of the market were studied, or even the Tourism potential was taken in consideration for the allocation of resources in RJ. It was identified some peculiar situations of municipalities such as Itatiaia and Cabo Frio, which had no action financed by MTur resources, which, in turn, were neglected to benefit municipalities such as São João do Meriti, Itaboraí and others in the state of RJ.

Table 4: Tourist categorization data for 2017.

\begin{tabular}{|l|l|l|l|l|l|l|}
\hline \multicolumn{1}{|c|}{ Tourist region } & \multicolumn{1}{|c|}{ Municipality } & \multicolumn{1}{|c|}{$\begin{array}{c}\text { Quantity Lodging } \\
\text { Jobs }\end{array}$} & \multicolumn{1}{|c|}{$\begin{array}{c}\text { Quantity Lodging } \\
\text { Establishments }\end{array}$} & $\begin{array}{c}\text { International } \\
\text { Flow }\end{array}$ & Domestic Flow & $\begin{array}{c}\text { Category } \\
\mathbf{2 0 1 7}\end{array}$ \\
\hline Agulhas Negras & Itatiaia & 524 & 96 & 5.677 & 99.260 & B \\
\hline Costa do Sol & Cabo Frio & 693 & 80 & 22.707 & 1.345 .732 & A \\
\hline
\end{tabular}

Source: Ministry of Tourism, adapted from the categorization of tourist municipalities (2017). 
In the universe of agreements/contracts, almost no actions were identified that make mention of tourist regions or even works and actions between tourist municipalities. The only mention of this type of situation was identified in two in the years 2012 and 2016. The first dealt with the construction of a gantry in Duque de Caxias, managed by the Secretariat of Works of the state of RJ, worth BRL 1,950,000 (one million, nine hundred and fifty thousand Brazilian Reais). The second agreement dealt with installing five tourist information offices in the municipality of Rio de Janeiro in the amount of BRL 460,000 (four hundred and sixty Brazilian Reais). These two agreements/contracts bring, in the description of the action, mentioning the benefits for several municipalities, however, the objects financed by them are singular and are directed to specific municipalities.

Following the analysis, the next step is to understand how these Tourism resources were used in the municipalities of the state. In this sense, Table 5 will provide a summary of the distribution of the use of resources in the eight categories of use, as well as the amount of municipalities and agreements/contracts established with the municipalities of Rio de Janeiro.

Overall, the state of RJ had 478 agreements/contracts established between the years 2004 to 2016. In Table 5, three categories of resource use were highlighted, they are: "Infrastructure", followed by "Urbanization and Public Squares". It is noticeable that the broader category is "Infrastructure", with 62 municipalities and 142 agreements/contracts, representing $30 \%$ of the resources. Soon after, comes "Urbanization" with 90 agreements/contracts established in 39 municipalities of RJ, this category represents $21 \%$ of resources. Third, the category "Public Squares" appears with 134 agreements/contracts in 54 municipalities, representing $19.5 \%$. If these three categories were aggregated, they would represent about $70 \%$ of the resources, a scenario that puts RJ with a higher concentration of resources than $\mathrm{RN}$, when it comes to the category of use.

The categories "Attractions" and "Tourist Signage" were at the same level, both in the number of municipalities and agreements/contracts. This fact highlights a certain asymmetry, since RJ held a significant amount of municipalities organized in tourist regions. However, it appears that investments in the "Attractions" category were low, which was left out of the other forms of use of the Ministry's resources.

The category "Gantries" and "Event Support" also had a number of similar resources; their representation in the amount was $4.8 \%$. However, only nine municipalities had agreements/contracts in the category "Event Support", with 10 agreements/contracts signed. On the other hand, the category "Gantries" includes 22 municipalities contemplated and 26 agreements/contracts signed with the same contribution of resources.

Finally, the category "Management Actions" was the smallest budget invested with a representation of $1 \%$ of the volume of resources, with only four agreements/contracts signed. Among them, two went to the municipality of Armação de Búzios with the elaboration of a marina project and improvements to the pier. The other two agreements/contracts were for the municipality of Rio de Janeiro, with tourist signage and accessibility projects in the city.

Table 5: Distribution of public resources by category of use in RJ (2004-2016).

\begin{tabular}{|l|l|l|l|l|l|}
\hline Resource Usage Category & Number of municipalities & Number of Agreements/Contracts & $\%$ & Invested value & $\%$ \\
\hline $1-$ Public Square & 54 & 134 & 28 & BRL 59.378.520.10 & 19.5 \\
\hline $2-$ Event Support & 9 & 10 & 2 & BRL 14.735 .000 .00 & 4.8 \\
\hline 3- Infrastructure & 62 & 142 & 30 & BRL 92.469.204.90 & 30.3 \\
\hline $4-$ Urbanization & 39 & 90 & 19 & BRL 64.208.663.40 & 21.0 \\
\hline $5-$ Management Actions & 2 & 4 & 1 & BRL 3.190.000.00 & 1.0 \\
\hline $6-$ Attractions & 24 & 38 & 8 & BRL 27.766.165.30 & 9.1 \\
\hline $7-$ Gantries & 22 & 26 & 5 & BRL 14.593.689.20 & 4.8 \\
\hline $8-$ Tourist sign & 22 & 34 & 7 & BRL 28.907.680.10 & 9.5 \\
\hline Total & - & 478 & $100 \%$ & BRL 305.248.923.00 & $100 \%$ \\
\hline
\end{tabular}


This panorama of the agreements/contracts of RJ outlines a scenario in which it is considered that the Ministry's resources have developed specific structures and without effective link with the development of Tourism, considering that categories such as "Attractions" and "Management Actions" occupy peripheral positions in investments.

To broaden the debate on the use of these resources in RJ, the 10 municipalities with the largest investments of Mtur were selected, considering the period 2004-2016. Next, Table 6 provides a detailed synthesis by categories of use of these investments.

In Table 6 (see Appandex), it should be noted that the municipalities of Rio de Janeiro and São João do Meriti, both are the main destination of MTur resources in the state. While Rio concentrates resources on "Tourist Signage, Public Squares and Attractions", São João do Meriti makes use mainly in "Public Squares, Urbanization and Event Support". Together these two municipalities cover about $45 \%$ of the resources; that is, they are two investment centers in the state of Rio de Janeiro, when the volume of resources per municipality is analyzed in the period from 2004 to 2016 .

According to Table 6, the most relevant categories of resources were "Infrastructure and Urbanization". In the "Infrastructure" category, the municipalities of Niterói, Nova Iguaçu, Itaboraí and Petrópolis stand out. In the category "Urbanization", there are Maricá, Paraty, São João do Meriti and Armação de Búzios.

It is important to mention that many objects belonging to partners are found as "Support for Tourism Infrastructure Projects", however, it is not possible to assess what type of object was materialized with these investments, since there is no more detailed information. The category of "Infrastructure" houses a range of objects, among them: renovations, extensions, modernizations and construction of related buildings and tourist circulation spaces.

It is noticed that many MTur resources are used to solve urban policy problems, such as sanitation, access, roads and even paving avenues. Certainly, Tourism can benefit from this type of improvement, but for these sectors, there are other bodies with significant performance, such as the former Ministries of Cities and National Integration that were in full operation at the time of these agreements/contracts. According to Cruz (2002) and Fonseca (2005), when studying PRODETUR, Tourism policy actions assumed the role of urban policy. Apparently, the versatility and complexity of Tourism are used as a cloak to cover up the biased use of resources, making it impossible to boost Tourism with this resource.

The third category to use MTur resources is the implementation of "Public Squares". In this category, three municipalities stood out, being: Rio de Janeiro, São João do Meriti and Itaboraí.

The category of "Public Squares" is relevant for the municipalities, as it is the most requested type of investment so far by the municipalities of RJ. This fact reinforces the understanding that these works, using MTur resources, have a greater relationship with political power than with the development of Tourism (Silva, 2015).

In the "Attractions" category, Rio de Janeiro, Angra dos Reis and Niterói had a higher performance. The features of the "Attractions" category were used to recover or improve some sights in RJ. It is noticed, in the research, that most of the resources that are classified as "Attractions", are, in fact, works on beaches, public bathing spots and viewpoints. The agreements/contracts revolve around the revitalization, small improvements, requalification and recovery of these spaces.

A highlight in the category "Attractions" is the municipality of Engenheiro Paulo Frontin, which is not among the 10 largest investments, but it is the one that has more agreements/contracts in this category, in total there are five agreements/contracts to implement the Lago Azul Tourist Complex ${ }^{8}$, with about BRL 1 million being allocated between the years 2005 to 2009 .

Next, Graph 1 summarizes the distribution of resources and ratifies the analyses made in this session on the municipalities of RJ, considering the investments made in each category of use by the ten largest investments in the state.

mostly between destinations "A and B". However, the presence of São João do Meriti, Itaboraí, Nova Iguaçu and Maricá, among the largest investments with categories "C and B", is not explained by economic data. In addition, the amount of resources exceeds the volume of resources for Armação de Búzios, Angra dos Reis, Petrópolis and Paraty, which presented superior results. Not to mention Itatiaia and Cabo Frio (mentioned earlier) 


\section{Jomat}

Graph 1: Distribution of resources in the 10 municipalities with the highest investment by category of use in RJ (2004-2016).

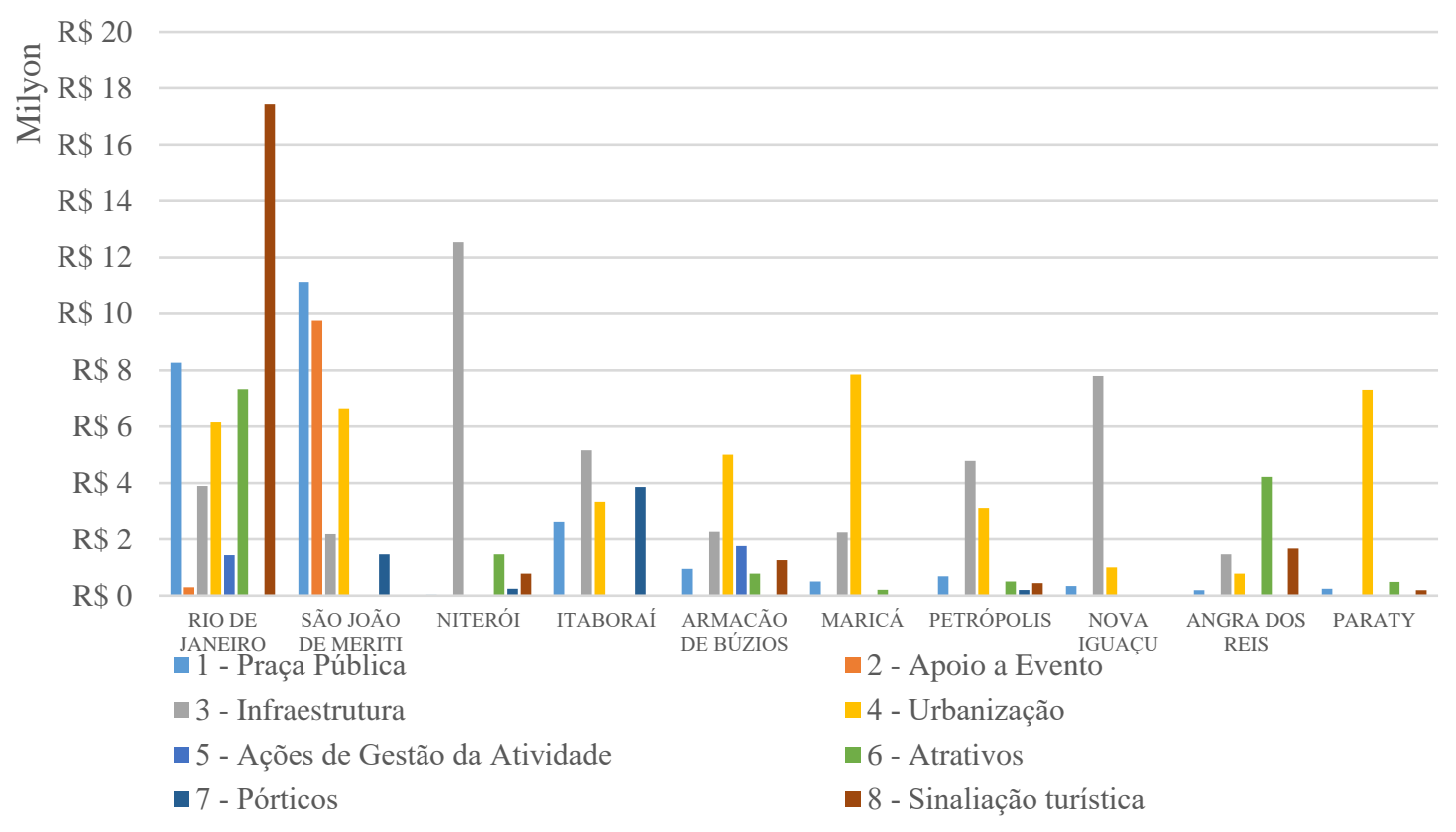

Source: SIACOR. Authors' elaboration

that do not have any investment, but, in return, have significant indicators.

The research in RJ showed that there are other elements and forces directing public resources, causing a deviation of the budget with guidelines instituted by the Tourism policy. Therefore, the RJ study points out that the technical and economic element in the Tourism area is not predominant in the receipt of resources.

According to Vieira et al. (2018), when studying public investments in 65 Brazilian tourist destinations, they concluded that the relationship between investment and competitiveness does not depend on the allocated volume of resources, but on the strategic orientation in use. In this sense, that study corroborates with this research, exalting the need to establish technical criteria capable of adequately directing government action in tourist municipalities.

\section{Final Considerations}

Considering that the objective of this research was to understand the intertwining between the PRT and public investments in Tourism in the state of RJ, inferences are possible: 1 - Belonging to the

Table 7: RJ categorization data -2017.

\begin{tabular}{|c|c|c|c|c|c|c|c|}
\hline Tourist region & Municipality & \begin{tabular}{|l|} 
Quantity \\
Lodging Jobs \\
\end{tabular} & $\begin{array}{l}\text { Quantity Lodging } \\
\text { Establishments }\end{array}$ & \begin{tabular}{|l|} 
International \\
Demand \\
\end{tabular} & $\begin{array}{l}\text { Domestic } \\
\text { Demand }\end{array}$ & Category & Total transfer \\
\hline Metropolitana & $\begin{array}{l}\text { Rio de } \\
\text { Janeiro }\end{array}$ & 16.721 & 484 & 1.458 .949 & 6.953 .904 & A & 44.801 .835 .90 \\
\hline Not Listed & $\begin{array}{l}\text { São João do } \\
\text { Meriti }\end{array}$ & 508 & 17 & 0 & 40.086 & B & 31.209 .955 .40 \\
\hline Metropolitana & Niterói & 789 & 36 & \begin{tabular}{|l|}
22.707 \\
\end{tabular} & 2.51 .967 & $\mathrm{~B}$ & 15.057 .644 .00 \\
\hline $\begin{array}{l}\text { Caminhos da } \\
\text { Mata }\end{array}$ & Itaboraí & 160 & 15 & 0 & 0 & $\mathrm{C}$ & 14.985 .000 .00 \\
\hline Costa do Sol & $\begin{array}{l}\text { Armação de } \\
\text { Búzios }\end{array}$ & 1.970 & 235 & 244.104 & 769.263 & A & 12.034 .569 .00 \\
\hline Costa do Sol & Maricá & 11 & 6 & 0 & 118.348 & $\mathrm{C}$ & 10.825 .956 .00 \\
\hline $\begin{array}{l}\text { Serra Verde } \\
\text { Imperial }\end{array}$ & Petrópolis & 968 & 91 & 17.031 & 211.881 & $\mathrm{~B}$ & 9.724 .564 .10 \\
\hline $\begin{array}{l}\text { Baixada } \\
\text { Fluminense }\end{array}$ & Nova Iguaçu & 429 & 7 & 0 & 32.450 & $\mathrm{C}$ & 9.141 .250 .00 \\
\hline Costa Verde & $\begin{array}{l}\text { Angra dos } \\
\text { Reis }\end{array}$ & 672 & 96 & 153.275 & 954.420 & A & 8.324 .250 .00 \\
\hline Costa Verde & Paraty & 738 & 130 & 124.891 & 488.663 & $\mathrm{~A}$ & 8.238 .750 .00 \\
\hline
\end{tabular}

Source: MTur, categorization 2017. Systematization by the authors. 
tourist region is not the funda mental criterion for receiving public resources. 2 - The technical criteria are not evident and the resources were distributed in a dispersed manner in several municipalities. 3 - The potential of some municipalities (Itatiaia and Cabo Frio) with better indicators was disregarded, to the detriment of others that did not present data that justify the concentrations of resources they received (São João do Meriti, Itaboraí and Nova Iguaçu). These situations show failures in investment management and misalignment of public Tourism policies.

It was possible to identify that almost all of the resources transferred by MTur were allocated in municipalities belonging to tourist regions (from 2006 to 2013 all municipalities in the RJ were considered tourist). However, some municipalities (Cabo Frio and Itatiaia) with strategic potential for the development and expansion of Tourism in the state were not contemplated with MTur resources. This reality evidenced in this research points to a random allocation of resources, and without clear technical criteria.

Regarding the use of public resources, investments continue to be mostly for urban infrastructure, following the movement of the 1990s, when PRODETUR had this objective. Large sums of resources have not been identified to remedy regional or even structural problems of Tourism in tourist regions. What can be inferred is that the resources are spread over several municipalities, without integration or even thinking about local realities, for this reason, large contributions were made to public squares, urbanization and infrastructure.

It is also noteworthy that there are almost no resources allocated in "Tourism Management Actions", that is, there was no preparation of the higher body of Tourism policy to create and promote Tourism development strategies in municipalities. The investment policy in Tourism follows a poorly visible line, in which it is not possible to understand the motivations, reasons or even lack of resources. One of the arguments that help to understand this investment scenario is to observe that there are great indications that most of these resources are from parliamentary amendments, and that these are used as an electoral campaign platform, implementing small and punctual works.

A limitation of this research is the impossibility of observing the uses of resources from 2017 onwards, a limitation generated by the database used. In this sense, it is advisable to use other databases such as: Plataforma Mais Brasil and the Transparency Portal.

It is believed that this work is still an initial step to open a line of research in the area of investments and consolidation of tourist destinations, because the literature is still scarce, and there are few works dedicated to understanding this dynamics of investments and consolidation of public policies, especially in the area of Tourism.

\section{References}

Banerjee, O., Cicowiez, M., \& Cotta, J. (2016). Economics of tourism investment in data scarce countries. Annals of Tourism Research. Retrieved from https://doi.org/10.1016/j.annals.2016.06.001

Beni, M. C. (2006). Política e Planejamento do Turismo no Brasil. ALEPH.

Brasil. (2003). Plano Nacional de Turismo 2003 -2007: Diretrizes, Metas e Programas. Retrieved from http://www.turismo.gov.br/sites/default/turismo/o _ministerio/publicacoes/downloads_publicacoes/p lano_nacional_turismo_2003_2007.pdf

Brasil. (2004). Mapa da regionalização do turismo. Ministério do Turismo - Brasília. Retrieved from http://www.turismo.gov.br/publicacoes/item/83mapa-do-turismo-brasileiro-2013.html

Brasil. (2007). Plano Nacional de Turismo 2007 - 2010. Retrieved

from http://www.turismo.gov.br/sites/default/turismo/o _ministerio/publicacoes/downloads_publicacoes/p lano_nacional_turismo_2007_2010.pdf

Brasil. (2009). Mapa da Regionalização do Turismo 2009 (p. 1). Retrieved from http://www.turismo.gov.br/sites/default/turismo/o _ministerio/publicacoes/downloads_publicacoes/ Mapa_novembro_2009.pdf

Brasil. (2013a). Mapa do Turismo Brasileiro. Retrieved from

http://www.turismo.gov.br/sites/default/turismo/o _ministerio/publicacoes/downloads_publicacoes/ Mapa_novembro_2013.pdf.

Brasil. (2013b). Plano Nacional de Turismo 2013-2016. Retrieved from ttp://www.turismo.gov.br/images/pdf/plano_nacio nal_2013.pdf

Brasil. (2018a). Estudo da demanda turística Internacional. Retrieved from http://www.dadosefatos.turismo.gov.br/images/D emanda_Turistica_InternacionalFichas_Sinteses_2013-2017.pdf

Brasil. (2018b). Plano Nacional de Turismo 2018-2022. Retrieved

from 
http://www.turismo.gov.br/images/pdf/PNT_2018 -2022.pdf

Brasil. (2016). Mapa do Turismo 2016. Retrieved from https://dados.gov.br/dataset/mapa-do-turismobrasileiro

Brasil. (2019). Mapa da regionalização do turismo 2019 2021. Retrieved from http://www.mapa.turismo.gov.br/mapa/init.html\# /home

Brusadin, L. B. (2005). Estudo da avaliação do Programa Nacional de Municipalização do Turismo - PNMT na gestão do presidente Fernando Henrique Cardoso. Revista Hospitalidade, 2(2), 87-111.

Coutinho, A. C. A. (2015). Políticas públicas, desenvolvimento local e participação social nas instâncias de governança associadas ao turismo no Rio Grande do Norte. (Dissertação de Mestrado). Universidade Federal do Rio Grande do Norte.

Cruz, R. C. (2002). Política de turismo e território. Contexto.

Duda, I. M., \& Araujo, L. M. (2014). Polos de turismo no nordeste do Brasil: crescimento, desenvolvimento e escassez de conhecimento. Caderno Virtual de Turismo, 14(23), 204-218. https://doi.org/10.4000/confins. 10031

Fagerlande, S. M. R. (2015). Penedo: a construção da imagem de uma cidade turística. Caderno Virtual de Turismo, 15(3), 276-289.

Fagerlande, S. M. R. (2010). Casa de Papai Noel de Penedo / Pequena Finlândia: turismo e cenarização. 1-13. Retrieved from http://www.labcom.fau.usp.br/wpcontent/uploads/2015/05/3_cincci/016-sergiofagerlande.pdf

Fonseca, M. A. P. (2005). Espaço, políticas de turismo e competitividade. EDUFRN.

Fonseca, M. A. P. (2011). Turismo e Divisão Territorial do Trabalho no Polo Costa do Sol/Rj. Mercator, 10(21), 121-132. Retrieved from https://doi.org/10.4215/rm2011.1021.0008

Fonseca, M. A. P., Bicalho, M. D., Souza, R. M., \& Silva, R. D. (2019). Programa De Regionalização Do Turismo: análise comparativa dos indicadores turísticos nos estados brasileiros de Santa Catarina, Rio de Janeiro e Rio Grande do Norte. Ar@ cne-Revista Eletrónica de Recursos En Internet Sobre Geografía Ciencias Sociales, 234, 1-20. Retrieved from http://www.ub.edu/geocrit/aracne/aracne-234.pdf

González, M. V. (2006). Gestión de destinos: ¿Gobernabilidad del turismo o gobernanza del destino? Actas de XVII Simposio Internacional de Turismo y ocio. Retrieved from https://www.researchgate.net/publication/23
7220955_GESTION_DE_DESTINOS_GOBERN ABILIDAD_DEL_TURISMO_O_GOBERNANZA _DEL_DESTINO

González, M. V. (2014). Governança Turística: políticas públicas inovadoras ou retorica banal? Caderno Virtual de Turismo, 14, 9-22.

González, M. V. (2016). Entre el poder y la racionalidad: gobierno del turismo, política turística, planificación turística y gestión pública del turismo. PASOS - Revista de Turismo y Patrimonio Cultural, 14, 577-594.

Hubner, D. B. (2013). Um turismo de base comunitária para o Parque Nacional do Itatiaia: estudo sobre conflito socioambiental em unidade de conservação. (Tese de doutorado). Universidade do Estado do Rio de Janeiro. Rio de Janeiro - RJ. Retrieved from http://www.nuredam.com.br/files/publicacoes/tes es/HUBNER_dr.pdf

Kis-Katos, K., \& Sjahrir, B. S. (2017). The impact of fiscal and political decentralization on local public investment in Indonesia. Journal of Comparative Economics. Retrieved from https://doi.org/10.1016/j.jce.2017.03.003

Lemos, C. C. (2013). Planejamento do turismo em âmbito federal: uma análise dos instrumentos utilizados e dos investimentos no setor. Revista de Administração Pública, 476). Retrieved from https://doi.org/10.1590/S003476122013000600004

Lima, R. M. M. (2017). Turismo, Políticas Públicas e Desenvolvimento: uma avaliação do Programa de Regionalização do Turismo nas cinco regiões turísticas do Rio Grande do Norte (2004-2014). (Tese de doutorado). Universidade Federal do Rio Grande do Norte. Retrieved from https://repositorio.ufrn.br/jspui/bitstream/123456 789/23754/1/TurismoPolíticasPúblicas_Lima_201 7.pdf

Mazón, T. (2014). El turismo lo bueno, lo feo y lo malo. COMPAS.

Moutinho, J. A. (2016). Transferências voluntárias da União para municípios brasileiros: mapeamento do cenário nacional. Revista de Administração Pública, 50(1), 151-166. Retrieved from https://doi.org/10.1590/0034-7612139003

Nóbrega, W. R. M. (2012). Turismo e políticas públicas na Amazônia brasileira: instâncias de governança e desenvolvimento nos municípios de Santarém e Belterra, oeste do estado do Pará. (Tese de doutorado) Universidade Federal do Pará

Paiva, M. D. G. D. M. (2010). Análise do programa de desenvolvimento do turismo do nordeste (Prodetur/NE) na perspectiva do planejamento estratégico. Revista de Administração Pública, 44(2), 197-213. Retrieved from 
https://doi.org/10.1590/s003476122010000200002

Silva, R. C. (2015). Política de regionalização de turismo no interior potiguar: articulação, entraves $e$ efetividade. (Dissertação de Mestrado) Universidade Federal do Rio Grande do Norte.

Silva, R. C. (2016). Processo de Regionalização do Turismo: quantificação e similitudes. In S. G. Vianna, Andreia de Albuquerque; Guardia, Mabel Simone; Batista (Org.), Turismo em Perspectiva Ensaios Multidisciplinares. Editora Primas.

Silva, R. C., \& Fonseca, M. A. P. (2017). Os investimentos do Ministério do Turismo e o Programa de Regionalização do Turismo: desencontros da política governamental no interior potiguar. Caderno Virtual de Turismo. Retrieved from http://www.ivt.coppe.ufrj.br/caderno/index.php/ca derno/index

Silva Junior, F. X., \& Silva, R. C. (2019). Interiorização e regionalização do Turismo Potiguar: Avaliação dos Investimentos públicos no polo Serrano. In Turismo em Foco (p. 55-64). Poisson.

Sztompka, P. (2016). Two Theoretical Approaches to Trust; Their Implications for the Resolution of Intergroup Conflict. In I. Alon \& D. Bar-Tal (Orgs.), The Role of Trust in Conflict Resolution (p. 15-21). Springer. Retrieved from https://doi.org/10.1007/978-3-319-43355-4

Todesco, C., \& Silva, R. C. (2017). Planejamento e execução Orçamentária em turismo no Brasil (2003-2016). Seminário Anual da Associação de Pesquisa e Pós-graduação em turismo-ANPTUR. Retrieved from https://www.sisapeventos.com.br/staff/serviceapp-android/creater.php/751

Todesco, C., \& Silva, R. C. (2021). Planejamento setorial e execução orçamentária em turismo no Brasil (2003-2018). Revista Brasileira de Pesquisa em Turismo, 15(2), 1986. Retrieved from https://doi.org/10.7784/rbtur.v15i2.1986

Vieira, D. P., Hoffmann, V. E., \& Alberton, A. (2018). Investimentos públicos, competitividade e desenvolvimento: um estudo em destinos turísticos brasileiros. Revista de Administração Pública, 52, 899-917. Retrieved from https://doi.org/http://dx.doi.org/10.1590/00347612174959

Yázigi, E. (2003a). Civilização urbana, planejamento e turismo: discípulos do amanhecer. Contexto.

Yázigi, E. (2003b). Turismo uma esperança condicional (3). Global. 
2021, SP (1): 133-149

https://doi.org/10.31822/jomat.2021-SP-1-133

\title{
INFO PAGE
}

\section{Regionalization and Public Investment: Analysis of the transfers of the Ministry of Tourism (MTur) in the state of Rio de Janeiro -Brazil}

\begin{abstract}
This article is dedicated to understanding the intertwining of two materializations of public Tourism actions, namely: the Tourism Regionalization Program (PRT) and the investments made by the Ministry of Tourism (MTur). This is a gap in the studies of public tourism policies, when trying to understand the effectiveness of public actions by the applied financial instruments (González, 2014). Thus, it is intended to align the resources allocated to the municipalities with the Tourism Regionalization Map, in order to spatialize these actions, discover possible concentrations and deepen the debate about ministerial action. Then, it is also intended to classify the use of public resources into categories of use $11-$ Public Square; 2 - Event Support; 3 - Infrastructure; 4 - Urbanization; 5 - Management Actions; 6 - Attractions; 7 -Gantries; 8 - Tourist Sign). The spatial focus of the research will be the state of Rio de Janeiro, the choice of this federative unit was due to its significant power of attracting international tourists, as well as being a consolidated destination in the Brazilian domestic market. The time frame starts in 2004, as it is the first year of implementation of the Tourism Regionalization Program (PRT), and ends in 2016, due to the data from the Transfer Contracts System of the Ministry of Tourism (SIACOR) having this limitation. About 478 agreements established between MTur and the municipalities of RJ were analyzed. The main results point to a distribution of resources without technical criteria. Among the 10 municipalities that received the most resources from MTur, at least 4 (São João do Meriti, Itaborai, Maricá and Nova Iguaçu) have no tourist representation and no relevant tourist attractions, or even belong to Tourism production chains. The main category of use of MTur resources in RJ are: Infrastructure (30.3\%), Urbanization (21\%) and Public Squares (19.5\%). The development of tourist attractions accounted for only $9.1 \%$ of all investment. In addition, the research points to important tourist municipalities in the state of RJ (Itatiaia and Cabo frio) that did not receive any agreement or funding from MTur. This paper contributes to elucidating the way MTur operates through the distribution of resources and their uses for the development of Tourism policies in the last decade.
\end{abstract}

Keywords: Tourism Regionalization program, public investment in Tourism, Public Tourism Policy, Ministry of Tourism

\section{Authors}

Rodrigo Cardoso da Silva: Conceptualization, Methodology, Software, Formal analysis, Investigation, Data Curation, Writing - Original Draft, $60 \%$
Writing - Review \& Editing, Visualization,

Author statement: Author(s) declare(s) that All procedures performed in studies involving human participants were in accordance with the ethical standards of the institutional and/or national research committee and with the 1964 Helsinki declaration and its later amendments or comparable ethical standards. Declaration of Conflicting Interests: The author(s) declared no potential conflicts of interest with respect to the research, authorship, and/or publication of this article 